\title{
'Dragged at Anne's Chariot Wheels': L.M. Montgomery and the Sequels to Anne of Green Gables ${ }^{\mathrm{I}}$
}

\section{Carole Gerson ${ }^{+}$}

'Elderly couple apply to orphan asylum for a boy. By mistake a girl is sent to them' $(S I I, 330) .{ }^{2}$ As later recounted in Montgomery's revised journals, an I 895 notebook jotting eventually resulted in a 1906 manuscript that was rejected by four major American fiction publishers before being accepted by the Boston firm of L.C. Page in 1907. Issued the following year as Anne of Green Gables, the book soon achieved world-wide recognition as a classic novel of girlhood and adolescence. 'They took it and asked me to write a sequel to it,' Montgomery wrote in her journal:

I don't know what kind of a publisher I've got. I know absolutely nothing of the Page Co. They have given me a royalty of ten percent on the wholesale price, which is not generous even for a new writer, and they have bound me to give them all my books on the same terms for five years. I don't altogether like this but I was afraid to protest, lest they might not take the book, and I am so anxious to get it before the public. It will be a start, even if it is no great success $(S I I, 33 \mathrm{I})$.

Success indeed it was. Classed as an 'overall bestseller' by Frank Mott, who states that Anne of Green Gables had sold between

+ Carole Gerson is a member of the Department of English at Simon Fraser University. Her publications include A Purer Taste: The Writing and Reading of Fiction in English in Nineteenth-Century Canada $(\mathrm{r} 989)$ and Canadian Poetry from the Beginnings through the First World War (selected with Gwendolyn Davies, 1994). She is also a director of the Canadian Publishers' Records Database. An earlier version of her paper was presented at the third annual meeting of SHARP (Society for the History of Authorship, Reading and Publishing), in Edinburgh, on I6 July 1995 . 
800,000 and 900,000 copies by 1947,3 the book had earned Montgomery over $\$ 22,000.00$ for more than 300,000 copies by the time a bitter lawsuit resulted in the sale of her copyright to Page in I919. 4

Before recounting Montgomery's long and troubled connection with her publisher, and her equally problematic relationship with her most famous character, I would like to explore the implications and expectations of Page's terms by situating Montgomery at the intersection of several specific issues. These are the contested literary and cultural value of the sequel; the publication of Canadian-authored books at the turn of the century, in particular series and sequels, and writing for children (two formulations which sometimes coincide); and the international commodification of children's literature in children's periodicals and series.

Positing that the sequel originates in a 'charismatic text' that has had 'an unusually powerful effect on a large reading public,' Terry Castle opens her discussion of Pamela Part 2 with the 'commonplace' assertion that 'sequels are always disappointing. ${ }^{\prime}$ The same generalization is applied more specifically to Anne of Green Gables in an article by Gillian Thomas that begins, 'It is a cliché of popular literature that sequels tend to be disappointing, and students of children's literature are all too sadly familiar with the decline of writers who turn themselves into human factories on the basis of a successful first book. ${ }^{6}$ Disappointing for whom, one might ask. For the general reading public, the audience and consumers of sequels, who have always been eager to buy not only additional Anne books, but more recently have been gobbling up associated texts such as the edited volumes of Montgomery's journals and newly issued collections of her scattered magazine stories? ${ }^{7}$ According to a recent analysis of Montgomery's readers, the sequels substantially reinforce the value of the originating book because they 'tell ... what happened later' and prolong the pleasure of inhabiting the 'alternate world' of Montgomery's fiction. ${ }^{8}$ Disappointing, then, for the publishers and marketers who realize sizable profits from such spinoffs as cookbooks, address books, birthday books, diaries, colouring books, abridged and re-written versions of the texts, as well as Anne dolls and girl-sized souvenier wigs with red braids? For the artists who produce and perform in television, ballet, and musical versions of Montgomery's works? ${ }^{9}$ For the province of Prince Edward Island, and especially the residents of Charlottetown and Cavendish, whose economy benefits enormously from the tourist industry generated by the popularity of Anne in North America and Japan? ${ }^{10}$ As if to emblematize the material value of Montgomery's book to 
Canada as a whole, in 1994 the Royal Canadian Mint issued a 22-karat gold coin commemorating Anne, featuring (in the words of the brochure) 'a young girl under a gazebo, daydreaming about the adventures of Anne of Green Gables.' With a face value of $\$ 200.00$ but selling for $\$ 399.95$, this was the most expensive item in the Mint's Christmas brochure - more highly priced than coins commemorating other national cultural icons such as the last RCMP Northern Dog Team Patrol (silver dollar priced at \$1 7.95 or \$24.50, depending upon the case), the National War Memorial (proof loonie priced at \$16.95), and the Home Front during the Second World War (\$100.00 gold coin priced at \$249.95). Clearly, the charisma of Anne of Green Gables spills far beyond the notions of value constructed by the traditional literary critic, into a dense web of cultural activity that includes romance and popular culture, national identity, provincial and international economics, and social history. Full analysis of these concerns would constitute an intriguing cultural studies project requiring a collaborative team of interdisciplinary experts; the intention of this essay is to discuss some of the earlier historical events and contexts that underpin the later commodification of L.M. Montgomery and her works.

At the turn of the century, Maud Montgomery was an unmarried woman in her late twenties, single-mindedly forging a commercially viable literary career by working her way upward from occasional newspaper poems and stories to larger commissions and serials in popular American periodicals like Outing and The Boy's World. Trapped in the rural community of Cavendish, Prince Edward Island, as the sole caretaker of her aging grandmother, even if she had so desired she could not have followed the route taken by Janet Royal, a secondary character in her 1925 novel, Emily Climbs, who moves to New York to pursue a successful career as a literary journalist. ${ }^{\text {II }}$ Nonetheless, like her Canadian-born predecessor Sara Jeannette Duncan, Montgomery well knew that 'the market for Canadian literary wares of all sorts is self-evidently New York. ${ }^{\text {I2 }}$ Although Duncan herself would later develop a substantial British readership, as would other Canadian authors with imperial connections and concerns such as Gilbert Parker and Stephen Leacock, her I 887 comment foretold the career orientation of the majority of ambitious Canadian authors around the turn of the century. A canny businesswoman, Montgomery recorded in her letters her preference to sell her work to American publications as they could pay substantially better than Canadian magazines. Regardless of her personal patriotism and her subsequent difficulties with Page, she 
declared she 'wouldn't give [a] Ms. to a Canadian firm. It is much better financially to have it published in the United States. ${ }^{\prime 2} 3 \mathrm{Her}$ comments on the selection of publishers to whom she first sent the manuscript of Anne of Green Gables demonstrate her pragmatic assesssment of the publishing industry. She began with Bobbs-Merrill as a new firm just establishing its list, then 'went to the other extreme and sent it to the MacMillan Co. of New York,' then tried Lothrop, Lee and Shepard, 'a sort of "betwixt and between" firm' specializing in juvenile series (including the series of boys' books written three decades earlier by fellow Maritimer, James De Mille), then Henry Holt $(S I I, 33 I)$, and finally, L.C. Page.

American publishers cater to American readers whose interest in Canada has historically been rather slight. However, these limitations appear to have been less stringent around the turn of the century, when Montgomery first broke into print. According to Pierre Berton, during the period before the Great War the American film industry was fascinated with Canada: ' $[t]$ he country, to most Americans, was almost unknown and therefore exotic. ${ }^{\prime 4}$ In the realm of popular fiction, the situation was more complex. First of all, virtually no Canadian authors attempting to support themselves by writing could afford to publish only in Canada, with a population (and book market) one-tenth of that of the United States. Secondly, prevailing market and copyright conditions prevented Canadian publishers from easily accessing American markets. Our grasp of the situation is hindered by the fact that co-publishing arrangments are often not indicated on title pages, which therefore may imply that a book was solely a Canadian product when it was actually issued in arrangement with an American firm. ${ }^{15}$ From my research on the papers of a number of Canadian authors, I think it likely that during Montgomery's lifetime (1874-1 942) no Canadianauthored popular fiction series appeared that was not published in the United States. ${ }^{16}$ For Montgomery, one of Page's initial attractions was the firm's recent publication of books by Charles G.D. Roberts and Bliss Carman, two major Canadian literary figures of Maritime origin like herself, who successfully established visible identities in the United States - although they both had to move there in order to do so, and both subsequently experienced considerable difficulty with Page. ${ }^{17}$

If the primary market was the United States, how appealing was fiction set in Canada? On the one hand, a number of American publishers successfully promoted Canadian-authored popular and juvenile fiction series (sometimes comprised of sequels) with 
distinctively Canadian settings. These include James De Mille's B.O.W.C. series set in the Grand Pré area of Nova Scotia (first published $1869-73$ and still in print with the Boston firm of Lee \& Shepard in the early I900s), Norman Duncan's Billy Topsail books (1906-I6, set in a Newfoundland not yet part of Canada), Ralph Connor's Glengarry series set in rural Ontario and the West / I goI33), Scribners' 23-volume edition of The Works of Gilbert Parker (I9I2-23), and somewhat later, Mazo de la Roche's Ontario-based Jalna books (1927-54) and Muriel Dennison's western 'Susannah of the Mounties' series (1936-40). On the other hand, it is known that several Canadian authors working in the market area of juvenile and popular fiction were required to change their Canadian settings to American locations in order to secure publication, such as Marshall Saunders for Beautiful Joe (1894) and Elsie Bell Gardner for her Maxie series of girls' adventure stories (I932-39). ${ }^{18}$ Still other professional writers occasionally placed their books in Canada without creating the national emphasis fostered by the geographical assertiveness of a distinct series; the list includes Zillah Macdonald, James Macdonald Oxley, and Helen Dickson Reynolds.

While it is always necessary to keep in mind the often precarious position of identifiably Canadian texts within the larger world of British and American publishing, more significant with regard to the development of Montgomery's career was the late nineteenthcentury explosion in commercial publishing aimed at children, particularly through the production of series. Series production, according to Norman Feltes, developed as the capitalist system's mode of controlling and profiting from commodity-texts by producing both the audience (i.e. the market) and the wares purchased and consumed by that market. ${ }^{19}$ In the realm of juvenile literature, this occurred in conjunction with the rapid expansion of children's periodicals in the second half of the nineteenth century, in both Britian and the United States, many originating as Sunday school publications. For example, series issued under the name of the American Tract Society gave the imprimatur of respectability to the often suspect genre of fiction. ${ }^{20}$ Faye Kensinger, whose Children of the Series documents the production of juvenile serial literature in the United States, reports two specific findings important for our understanding of the atmosphere into which Montgomery launched herself as an author: series aimed specifically at girls were especially likely to follow the maturation of the main character - i.e. to be sequels rather than a chronologically static sequence of vacation adventures; and series production peaked during the second decade 
of the twentieth century - the decade when Montgomery produced most of the Anne books.

However, our full understanding of the production of Montgomery's books is seriously hampered by the lack of surviving archival material. Lewis Page's personal and business papers seem to have vanished, as has Montgomery's correspondence with her publishers. Although she does state in her journal that she was saving her business papers for her biographer, that package has since gone astray. ${ }^{2 I}$

Available evidence suggests that Lewis Page was an exploitive publisher who grew increasingly difficult over the years due to his volatile temperament and his costly recreations of gambling and philandering, neither of which endeared him to an author who in I9I I became the wife of a Presbyterian clergyman. ${ }^{22}$ Intersecting with this personal level of antagonism were conflicts stemming from the changes in practices and attitudes analyzed by Norman Feltes in his two books on the evolving structure of publishing in the nineteenth and earlier twentieth centuries. While Montgomery wanted to make money, like most authors she also aspired to literary respectability and thought of herself as an artist who should control the terms of her work. Page, however, as a commercial entrepreneur, regarded her as the producer of raw material for the process of book production over which he had absolute control. ${ }^{23}$ From the time he established his company in 1896 , his staple was juvenile series, beginning with Annie Fellows Johnston's I 2-volume Little Colonel series that eventually sold over a million copies. ${ }^{24}$ In Feltes's terms, Page was a 'speculative' publisher whose acceptance of Anne of Green Gables was a gamble on the value of 'future texts' to be produced by Montgomery. ${ }^{25}$ Hence, while Montgomery seemed surprised and pleased that Page requested a sequel upon his acceptance of Anne of Green Gables, to Page, who inevitably viewed the first Anne book as the beginning of a series, there was nothing unusual about requesting a 'second story dealing with the same character ${ }^{26}$ long before the originating text had been produced and tested in the market. In other words, the second Anne book, Anne of Avonlea, was generated not by the clamour of enchanted readers, but by the current practices of market publishing; the charismatic quality of Anne of Green Gables was not substantive to the production of its initial sequels, but rather an incidental surprise. In fact, in the spring of 1909 Page decided to delay the appearance of Anne of Avonlea until the following autumn to avoid competition with the unexpectedly brisk sales of Anne of Green Gables. ${ }^{27}$ Moreover, Page's contracts did not distinguish between 
sequels and series; his reiterated demand for Montgomery's books for the next five years, whatever they happened to be, indicates that he saw his product as commodity-texts whose selling point was Montgomery's name, rather than as the on-going story of a character named Anne. ${ }^{28}$ This interpretation is borne out by the uniform appearance of all Montgomery's books issued by Page $(S / 2,134)$, and by his insistence on symmetrical titles. ${ }^{29}$

In light of the publishing structure of her era, the interesting question is whether or not Montgomery at some level expected to write a sequel to Anne of Green Gables: was it a text originally envisioned as closed and complete? On Io September 1908, while she was struggling with Anne of Avonlea, Montgomery wrote to Ephraim Weber that she agreed with reviewers of Anne of Green Gables that 'the ending was too conventional.' She then added: 'if I had known I was to be asked to write a second Anne book I wouldn't have "ended" it at all but just "stopped." '3० Anne of Green Gables concludes with Anne relinquishing a university scholarship in order to teach in the local school and support her beloved aging adoptive mother. In the book's social context, this decision represents a mature choice to assume responsibility and conform to community norms with regard to both class and gender, teaching being one of the few respectable paid occupations for impecunious young women of Montgomery's own social class. Yet deliberately or not, Montgomery left open a broad range of subsequent narrative possibilities. First of all, while she initially resisted the conventional closure of marriage (it takes three books to marry off Anne, as it would later take three books to marry off Emily), one would be hard put to name a contemporary primary female fictional character who doesn't eventually marry - unless she dies. Furthermore, in Montgomery's romance world, which permits surprise legacies and other delightful turns of fortune, there is no irrevocable reason why Anne should not get a later chance at university (as she will in Anne of the Island); in the meantime, her impending experiences as a teacher provide ample opportunity for Montgomery to further develop what will become her usual episodic narrative mode, composed of relatively discrete sequential stories and events unified by theme and character rather than by plot. Indeed, many earlier and contemporary authors turned the novel of adolescence into a narrative sequence on family life, beginning with Louisa May Alcott and continuing with sequential series like the What Katy Did books by 'Susan Coolidge' (Sarah Chauncey Woolsey) and Harriet M. Lothrop's stories of the Five Little Peppers. In 
other words, while Montgomery might not have openly acknowledged (even to herself) the possibility of writing a sequel, she had nonetheless prepared the way. Once she got started, sequels and sequences proved her natural mode, only five of her eventual twenty-two volumes of fiction being unattached narratives (Kilmeny of the Orchard, The Blue Castle, Magic for Marigold, A Tangled Web, and Jane of Lantern Hill). ${ }^{3 \mathrm{I}}$

To support this interpretation, Montgomery's journals, novels and letters offer ample evidence of her acquaintance with the practices of series publication outlined above. She frequently refers not only to Louisa May Alcott, whose books she knew well, but also to more ephemeral series like the Pansy books (SI I, 37) and Marietta Holley's Samantha books (SI I, 282). As well, her familiarity with periodical publishing for children necessarily brought her into contact with the inter-connections between the publishing of children's periodicals and the production of series of children's books. ${ }^{32}$

Montgomery's complex relationship with the fictional Anne Shirley is entangled with her equally complex relationship with the very real Lewis Page. The situation is further complicated by the lack of surviving primary sources other than Montgomery's journals. Her biographers suggest that at times she shaped her life to fit the narrative of her journals. ${ }^{33}$ However, in view of her later preparation of these personal writings for public view, with ample opportunity to adjust her wording while she recopied the text and added numerous photographs, it is more than likely that this professional storyteller shaped her own story retrospectively, along specific narrative lines. In a sense, the journals can be seen as a running sequel to her life and her published books. Thus, when upon first meeting Page in November, I9I0, she records in her revised journal 'I do not trust him' $^{\prime}\left(S J_{2}, 25\right)$, we cannot know if this was her actual impression at that time or a later reinterpretation, since she recopied these portions of her original diaries in late 1920 and through I92 I, while in the throes of lawsuits and countersuits with Page. According to notes from her now destroyed correspondence with John McClelland, it was only in early 1916 that she began to seriously doubt her publisher: 'Three months ago, I had no real distrust of Mr. Page in any way. Since then I have heard so much against him and his methods from different quarters that I am distrustful; but the fact of his threatening me with "the courts" is the one thing that has really turned my former loyalty into suspicion.' ${ }^{34}$ Similarly, we cannot know whether the quotation that opens this paper represents her actual thoughts in August 1907, or if her words have been 
recast as the beginning of a rather gothic tale about an innocent female writer's struggle to escape the magnetism and power of a wily publisher determined to extract sequels from her for the rest of her days. Certainly her letter to Ephraim Weber of 2 May 1907, announcing the acceptance of Anne of Green Gables, is less apprehensive. Here she describes Page as 'a good company' that 'has published several successful books by well-known authors, including Charles G.D. Roberts and Bliss Carman.' She mentions nothing about her stingy royalty agreement, and although a little uneasy about being committed for the next five years, she takes the binding clause as 'rather complimentary. ${ }^{\prime 35}$

When Montgomery commenced her second Anne book, her journals describe how her initial pleasure in returning to her fictional character - 'Anne is as real to me as if $I$ had given her birth - as real and as dear' $(S I I, 332)$ - soon yielded to frustration: 'My publishers are hurrying me now for the sequel. I'm working at it but will not make it as good as Green Gables. It doesn't come as easily. I have to force it' $\left(S I_{I}, 336\right)$. In Montgomery's case, the disappointment generated by sequels includes the plight of the author, now fearing she is 'to be dragged at Anne's chariot wheels the rest of my life. ${ }^{36}$ Trapped in Lewis Page's on-going binding contracts, she produced Anne of Avonlea (r909), Chronicles of Avonlea (19 1 2), and Anne of the Island (1915) (as well as three other unrelated books: Kilmeny of the Orchard, 1910; The Story Girl, I9I I; The Golden Road, I 1 I 2). Her journal records that in September I9I 3, she 'began work on a third "Anne" book. I did not want to do it. But Page gave me no peace and every week brought a letter from some reader pleading "for another Anne book." So I have yielded for peace sake. It's like marrying a man to get rid of him' $(S / 2,133)$.

This troubling, ironic image (suggesting a dynamic that we now associate with battered-wife syndrome) adumbrates the gendered subtext of Montgomery's narrated relationship with Page, in which her gratitude to him for having launched her career conflicts with her anger at the knowledge that his royalty arrangements have paid her less than half of what she should have received $(S / 2,17 \mathrm{I})$. After signing two contracts promising him all her books for the next five years, she determines to break what threatens to become an eternal commitment. But in November I 9 Io Page cunningly invited her to Boston for a fortnight, during which visit he wined and dined her so graciously that as his guest, despite her 'disgust' with the 'binding clause' $\left(S J_{2}, 25\right)$ she once again signed away her books for the next five years. 
This would, however, be the last such contract. Montgomery does not seem to have considered seeking professional assistance until 1916, when she joined the Author's League of America. That year she gained some control over her lucrative series of Anne sequels by selecting John McClelland as her Canadian publisher and literary agent, to whom she assigned the task of negotiating a better deal with an American firm. Out of good will she insisted on giving first refusal to Page, who instead responded aggressively, with a threat to sue for the rights to Anne's House of Dreams. When McClelland concluded an agreement with Frederick Stokes for the American publication of Montgomery's books, there ensued a legal war with Lewis Page and his brother George, paralleling in intensity the narrative of the First World War that dominates her journal at this time. Further complicating the picture was her view that 'The Page firm are the best bookmakers in America. Everybody admits that' $(S / 2,188)$ - a detail that would explain why Page seemed to thrive, despite the complaints of booksellers $(S / 2,176)$, authors $(S / 2,188$, I93), and former employees (SI2, I82). Montgomery's suit against Page for unpaid royalties $\left.(S)_{2}, 284\right)$ ended with his firm buying out the rights to her earlier books for $\$ 18,000.00$ - 'nothing like the value of my books,' she fumed, 'But with a pair of scoundrels like the Pages, a bird in the hand is worth half a dozen in the bush' (SI2, 285). Page then countered with the unauthorized publication of the only known text that could be described as a 'false sequel' to Anne. Further Chronicles of Avonlea, cobbled together in Page's office from discards from Chronicles of Avonlea that were still in his possession, was manufactured uniformly with the earlier Anne books. Montgomery sued again, he threatened counter-suits, and then dealt the greatest blow of all by selling the film rights to Anne of Green Gables for $\$ 40,000.00 .{ }^{37}$

Montgomery's disputatious relationship with Page placed her in good company, insofar as his dealings with other Canadian authors can be determined. In 1908 Charles G.D. Roberts complained bitterly that Page had 'acted abominably' by attempting to force him into 'new \& disadvantageous contracts' and later had great difficulty reclaiming rights to poems ever published by Page. ${ }^{8}$ Bliss Carman ran into similar copyright altercations, ${ }^{39}$ as did John Garvin when compiling Canadian Poems of the Great War (1918).40 The experiences of Marshall Saunders, author of the best-selling Beautiful Joe and other turn-of-the-century animal stories, corroborated Montgomery's view that 'the man must simply have an obsession of dishonesty' $\left(S / 2,3 \mathrm{I}_{3}\right)$. 
For Montgomery, extricating herself from Page did not, however, mean extricating herself from Anne. Anne's House of Dreams (1917), the first Anne book issued under her new terms with McClelland and Stokes, was followed by Rainbow Valley (1919) and Rilla of Ingleside (I92 I). Indeed, it was the continuing appeal of the Anne books that produced terms with Stokes so good that, she wrote, they 'rather frighten me. Can I continue to write up to them? I am always haunted by the fear that I shall find myself "written out" ' (ST2, 198). Upon completing Rainbow Valley she complained, 'I want to do something different. But my publishers keep me at this sort of stuff because it sells and because they claim the public, having become used to this from my pen, would not tolerate a change' (S/2, 278). Finally, in August I920, she declared, 'To-day I wrote the last chapter of "Rilla of Ingleside." I don't like the title. It is the choice of my publishers. . . The book is fairly good. It is the last of the Anne series. I am done with Anne forever - I swear it as a dark and deadly vow' $(S / 2,390)$.

Montgomery may have been done with Anne, but Anne was scarcely done with Montgomery. Still to come were Anne of Windy Poplars (1936) and Anne of Ingleside (1939), as well as a manuscript of previously written stories linked by Anne, 'The Blythes are Quoted,' which was eventually edited by Montgomery's son, Stuart MacDonald, and issued posthumously as The Road to Yesterday (1974). The production of these last books presents a poignant conclusion to the story of Montgomery's sequels. ${ }^{4}{ }^{1}$

The first six Anne books form a classic Bildungsroman sequence, following the major character through girlhood to maturity as the captivating, iconoclastic child fades into a sedate doctor's wife. Once married, Anne slips to the margins of her books, becoming incidental to the major story - a point discussed by Gillian Thomas. Replaced as a centre of interest by her children and assorted members of the community, she presides over her household as the image of the idealized good mother (reminiscent of Alcott's Marmee) that Montgomery, orphaned at the age of two, missed in her own life and proved unable to enact with her own children. Despite her complaints about the expectations of her publishers and public, the continued production of Anne books allowed Montgomery to have her cake and eat it too: to profit from the insatiable market for Anne books while using them as an opportunity to tell other stories, such as the experiences of women and children less fortunate than Anne ${ }^{42}$ as well as the depiction of daily life on the home front during the First World War presented 
through the maturation of Anne's youngest daughter in Rilla of Ingleside ${ }^{43}$ Because the previous texts presented discrete portions of Anne's life rather than a uniform, chronological narrative, Montgomery had left sufficient gaps into which she could later insert new texts. Thus the last books, set around the beginning of the twentieth century, coincide chronologically with Montgomery's own halcyon years, before the upheavals of the First World War, lawsuits, the I9I9 death of her best friend, and the onset of her husband's mental illness.

Montgomery's decision to write again about Anne derives from many factors: her economic precariousness due to the Depression, the purchase of a new home, and a switch in her English publisher (from Hodder and Stoughton to Harrap); her publishers' and readers' continuing requests for more Anne books; and above all, the popular success of the 1934 talking film version of Anne of Green Gables. An avid movie-goer, Montgomery quite liked the film despite its altered ending, although she found little connection between what she saw on the screen and her own notion of her characters.

In I935, ill and depressed due to difficulties with her husband and sons, Montgomery approached her return to the world of Anne with mixed feelings. On the one hand, she wondered if she would be able to " "get back into the past" far enough to do a good book'; on the other, she found the work therapeutic: 'I had a strange feeling when I sat down to my work. Some interest seemed to return to life. The discovery that I may still be able to work heartens me, so often lately I have been afraid I never could again. ${ }^{44}$ The writing of a chapter of Anne of Windy Poplars, she recorded six months later, 'seemed like escaping back into the past. I am feeling so much better - have begun to sleep normally again. ${ }^{\prime 45}$ Similar dynamics, intensified by her ever-increasing distress at the continuing deterioration of her husband's condition, of her own health, and of the European political situation, accompanied the composition of her last Anne book three years later. At the age of 63 , less than four years before her death, she wrote:

On this cool dark and muggy day I sat me down and began to write 'Anne of Ingleside.' It is a year and nine months since I wrote a single line of creative work. But I can still write. I wrote a chapter. A burden rolled from my spirit. And I was suddenly back in my own world with all my dear Avonlea and S . . [Summerside] friends again. It was like going home. ${ }^{46}$ 
Sequels were a determining factor in Montgomery's literary and personal life, producing the launch of her first book and her financial well-being, as well as decades of bitter dispute with her publisher and a problematic relationship with an intrusive, adoring readership. In her last years, they provided a refuge from an increasingly troubled world. By the end of Montgomery's life, sequels had ceased to be disappointing. For her publishers and other beneficiaries of the Anne industry, the sequels and spinoffs of Anne of Green Gables continue to produce tremendous profits. And for her public, who today still eagerly welcome every new text written by or associated with Montgomery, there can never be enough of Anne.

\section{RÉSUMÉ}

Cet article traite de la suite d'Anne of Green Gables en examinant la relation de L.M. Montgomery avec son personnage le plus connu, Anne Shirley, et avec son éditeur, L.C. Page. L'analyse situe l'auteure et son livre dans des zones en même temps spécifiques et reliées entre elles: le phénomène de la suite littéraire; la publication d'ouvrages d'auteurs canadiens au tournant du siècle, en particulier des séries et suites ainsi que des ouvrages pour jeunes filles; et la commercialization internationale de la littérature enfantine dans les périodiques et séries pour enfants.

\section{NOTES}

I I would like to thank Professor Mary Rubio of the English Department at the University of Guelph for sharing some of her research materials on L.M. Montgomery; and both Dr. Rubio and Nancy Sadek, former Head of Archival and Special Collections at the University of Guelph Library, for facilitating my access to Montgomery's unpublished journals. Anne Goddard at the National Archives of Canada, and Carl Spadoni and Renu Barrett at the William Ready Division of Archives and Research Collections, McMaster University, provided valuable assistance with material relating to the publishing history of the Anne books. And I am grateful to my colleagues in the English Department at Simon Fraser University, Paul Budra and Elizabeth Schellenberg, for setting this project in motion with their request for a contribution to their projected volume of essays, Part Two: Reflections on the Sequel.

2 Mary Rubio and Elizabeth Waterston, eds., The Selected Journals of L.M. Montgomery, Volume I (I889-19I0); Volume II (I9IO-I92I); Volume III (I92I-1929). 
(Toronto: Oxford University Press, 1985, 1987, 1992). Citations are identified as $S I$, followed by volume and page numbers.

3 Frank Mott, Golden Multitudes (New York: Bowker, 1947), 312.

4 Mary Rubio, 'The Architect of Adolescence,' in Mavis Reimer, ed., Such a Simple Little Tale: Critical Responses to L.M. Montgomery's Anne of Green Gables (Metuchen, N.J. and London: Children's Literature Association and Scarecrow Press, 1992), 67.

5 Terry Castle, Masquerade and Civilization: The Carnivalesque in EighteenthCentury Culture and Fiction (Stanford: Stanford University Press 1986), 133-5.

6 Gillian Thomas, 'The Decline of Anne: Matron vs. Child,' in Reimer, ed., Such a Simple Tale, 23.

7 These are (to date): The Doctor's Sweetheart and Other Stories, ed. Catherine McLay (Toronto: McGraw, 1979); Akin to Anne, ed. Rea Wilmshurst (Toronto: McClelland and Stewart, 1988); Along the Shore, ed. Rea Wilmshurst (Toronto: McClelland and Stewart, 1989); Among the Shadows, ed. Rea Wilmshurst (Toronto: McClelland and Stewart, 1990); After Many Days: Tales of Times Past, ed. Rea Wilmshurst (Toronto: McClelland and Stewart, 199r); Against the Odds: Tales of Achievement, ed. Rea Wilmshurst (Toronto: McClelland and Stewart, 1993); At the Altar: Matrimonial Tales, ed. Rea Wilmshurst (Toronto: McClelland and Stewart, 1994); Across the Miles: Tales of Correspondence, ed. Rea Wilmshurst (Toronto: McClelland and Stewart, 1995); Christmas with Anne and Other Holiday Stories, ed. Rea Wilmshurst (Toronto: McClelland and Stewart, 1995).

8 Catherine Sheldrake Ross, 'Readers Reading L.M. Montgomery,' in Mary Rubio, ed., Harvesting Thistles: The Textual Garden of L.M. Montgomery (Guelph, Ont.: Canadian Children's Press 1994l, 30.

9 Mavis Reimer claims that a ballet version is regularly performed at Christmas in her home town (Reimer, Such a Simple Tale, 2). The musical version is a ritual component of the Charlotttetown Festival held every summer in Prince Edward Island. For a discussion of the televised version, see Susan Drain, ' "Too Much Love-Making": Anne of Green Gables on Television,' The Lion and the Unicorn, 11 , no. 2 (1987): 63-72. Another spinoff is critiqued by Virgina Careless in 'The Highjacking of Anne,' Canadian Children's Literature 67 (I992): 48-56.

Io See Douglas Baldwin, 'L.M. Montgomery's Anne of Green Gables: The Japanese Connection,' Journal of Canadian Studies 28, no. 3 (1993): 123-33; Diane Tye, 'Mutiple Meanings Called Cavendish: The Interaction of Tourism with Traditional Culture,' Journal of Canadian Studies 29, no.I (I994): 122-34; Calvin Trillin, 'Anne of Red Hair: What do the Japanese see in Anne of Green Gables,' New Yorker, 5 August 1996, 56-61.

I I See Carole Gerson, 'Canadian Women Writers and American Markets, I880I940,' in Camille La Bossière, ed., Context North America: Canadian/U.S. Literary Relations (Ottawa: U of Ottawa P, 1994): 106-I 8.

I2 Sara Jeannette Duncan, 'American Influence on Canadian Thought,' The Week, 7 July $1887,518$.

I3 Montgomery, The Green Gables Letters, ed. Wilfrid Eggleston (Toronto: Ryerson, 1960$), 46,59,80$. 
I4 Pierre Berton, Hollywood's Canada: The Americanization of Our National Image (Toronto: McClelland and Stewart, 1975), I 8.

I5 This problem is complicated by R.E. Watters's practice, in his Checklist of Canadian Literature and Background Materials, 1628-1960/still the closest we have to an inclusive bibliography of Canadian literature in English), of citing the earliest imprint (whether Canadian, American, or British) located in a library, without seeking the variants that document co-publishing arrangements (admittedly, a gargantuan task, as he states in his Preface, xi). Hence, for example, his listing of Ralph Connor's novels Black Rock (r898), The Man from Glengarry (1901), The Major (1917), The Sky Pilot in No Man's Land (1919), and Treading the Winepress (1 925 ), all of which had British and American publishers, suggests they were solely Canadian productions (pp. 297-9).

I6 Outside the realm of fiction, the only known series published in Canada and not issued simultaneously elsewhere is The 'All Canadian' Entertainment Series, plays in pamphlet form all written by Edith Lelean Groves for children, published during the First World War by William Briggs and later by McClelland, Goodchild and Stewart.

17 Montgomery, Green Gables Letters, 52.

I8 Through the I930s to the I960s, serious writers like Morley Callaghan and Hugh MacLennan constantly wrestled with the problem of Canada's viability as an internationally recognizable setting for fiction. Because he sought an American readership, Sinclair Ross's classic novel of Depression life on the prairies, As For Me and My House (r94I), contains nothing to identify the setting as Canadian.

I9 Norman Feltes, Modes of Production of Victorian Fiction (Chicago: University of Chicago Press, I986), 9-1 2.

20 Faye Kensinger, Children of the Series and How They Grew (Bowling Green, Ohio: Bowling Green State University Popular Press, 1987l, 19.

2I Personal comunication from Mary Rubio, Montgomery's current biographer, I 3 September 1995. In 1986 the National Archives of Canada acquired eight contracts between Montgomery and L.C. Page as well as a 1919 memorandum concerning their lawsuit (MG $30 \mathrm{D} 342$ ). In the papers of J.G. McClelland in the William Ready Division of Archives and Research Collections at McMaster University, an undated typescript (624 pp.) of Montgomery's 'The Blythes are Quoted' is extant. In addition, there is a photograph album entitled 'A Little Souvenir of Green Gables and Avonlea' (compiler unknown, see the 1988 accession, box 3I, files IO-II). Unfortunately, the records of McClelland and Stewart, which contained Montgomery's correspondence with $M$ \& S, were destroyed some time after George Parker completed his doctoral dissertation, 'A History of a Canadian Publishing House: A Study of the Relation between Publishing and the Profession of Writing, 1890-1940' (University of Toronto, I969). Parker's notes, available at McMaster University, are the only resource concerning Montgomery's relations with $\mathrm{M} \& \mathrm{~s}$.

22 There is very little information available about Page, other than the entry by Margaret Becket and Theodora Mills in volume 49 of the Dictionary of Literary Biography. I would like to thank Sid Huttner at the University of Tulsa for his 
assistance with references to Page. Montgomery's published journals refer many times to Page's gambling and philandering (see $S / 2,117,226$ ).

23 Norman Feltes, Literary Capital and the Late Victorian Novel (Madison, University of Wisconsin Press, 1993/, 15.

24 Margaret Becket and Theodora Mills, 'L.C. Page and Company,' Dictionary of Literary Biography vol. 49 (1986): 349-5 I.

25 Feltes, Literary Capital, 18, 25.

26 L.C. Page \& Company to Miss L.M. Montgomery, 8 April I907, XZI MS A09801 2, L.M. Montgomery Collection, Archival Collections, University of Guelph Library. This is the only letter from Page in this collection.

27 Montgomery, Green Gables Letters, 85.

28 Another of his projects that included Canadian authors was his 'Little Cousin' books, a schoolrooom series that included contributions by Jane Roberts MacDonald (Our Little Canadian Cousin I. The Maritime Provinces, 1904), Mary Solace Saxe (Our Little Quebec Cousin, 1919), and Emily Murphy (Our Little Canadian Cousin of the Great Northwest, 1923).

29 Montgomery wanted the second book to be called The Later Adventures of Anne, not Anne of Avonlea (Green Gables Letters, 85), and disliked the title Anne of the Island $\left(S J_{2}, 163\right)$. The titles of Kilmeny of the Orchard $\left.(S J), 362\right)$ and Chronicles of Avonlea were also Page's creation, the latter, in Montgomery's view, a 'somewhat delusive title' (S/2, 94). Further Chronicles of Avonlea (1920), the unauthorized collection issued by Page was presented as an Anne book (S/2, $376)$. In addition, the maturity of the red-headed young woman appearing as the cover portrait on all the Anne books predicts the direction of the series.

30 Montgomery, Green Gables Letters, 70-I.

3 I However, it should also be noted that none of her other sequences trailed on as did the Anne books. Rather, she limited them to two pairs (The Story Girl and The Golden Road; Pat of Silver Bush and Mistress Pat) and one trilogy (Emily of New Moon, Emily Climbs, Emily's Quest).

32 See Kensinger, Children of the Series and How They Grew, 16-7.

33 Mary Rubio and Elizabeth Waterston, Writing a Life: L.M. Montgomery (Toronto: ECW Press, 1995l, 36.

34 Montgomery to John McClelland, 29 April 1916; George Parker's notes, McClelland and Stewart Archives, McMaster University.

35 Montgomery, Green Gables Letters, 52.

36 Ibid., 74.

37 Louisa May Alcott encountered similar difficulties when she attempted to change her publisher. See Martha Saxton, Louisa May: A Modern Biography of Louisa May Alcott (Boston: Houghton Mifflin, 1977), 317.

38 See Laurel Boone, ed. The Collected Letters of Charles G.D. Roberts (Fredericton, N.B.: Goose Lane Editions, 1989|, 287, 380, 450, 589, 600, 606.

39 See Muriel Miller, Bliss Carman: Quest \& Revolt (St. John's: Jesperson Press, 1985), 206, 254.

40 Arthur Stringer to John Garvin, I December [no year], Queen's University Archives, Lorne Pierce Collection, A.ARCH 200Ib Bo32 Foo7 II3. Arthur 
Stringer's correspondence with literary agent Paul Reynolds refers to yet another dispute with Page, eliciting from Reynolds the comment that Page 'is a smart, shrewd fellow but he will bear watching.' Reynolds to Arthur Stringer, 30 March 1905, Paul R. Reynolds papers, Box I66, Butler Library, Columbia University. I would like to thank Clarence Karr, Malaspina University College, for these two references.

4I The complexity of establishing Montgomery's publishing history is illustrated by the manuscript of Anne of the Island, at the Confederation Centre in Charlottetown, some pages of which are written on the backs of typescripts of what appear to be stories extracted from some of Montgomery's previously published books. While there is no bibliographical evidence that these stories were actually published, their format indicates that Montgomery intended to send them out to magazines. The cover page of one story, "Anne Comes to Grief in an Affair of Honour" (chapter 23 of Anne of Green Gables), states that it is "I,000 words" and gives the author's address as Leaskdale, thus dating it before Montgomery's 1925 move to Norval. While not sequels, if ever published such extracted stories would represent an interesting extension of the Anne books as well as an effort to get back at Page.

42 See Gillian Thomas, 'The Decline of Anne: Matron vs. Child'; Mary Rubio, 'Subverting the Trite, L.M. Montgomery's Room of Her Own,' Canadian Children's Literature 65 (1992): 6-39; Jennie Rubio, "'Strewn with Dead Bodies": Women and Gossip in Anne of Ingleside,' in Mary Rubio, ed., Harvesting Thistles, 167-77.

43 See Alan R. Young, 'L.M. Montgomery's Rilla of Ingleside (1920): Romance and the Experience of War,' in Gwendolyn Davies, ed., Myth and Milieu: Atlantic Literature and Culture, 1918-39 (Fredericton: Acadiensis, 1993): 95-122.

44 Journals of L.M. Montgomery, 9 March 1935, XZ 5 MS Aoor, vol. 9, L.M. Montgomery Collection, University of Guelph.

45 Ibid., 9 November 1935.

46 Ibid., 12 September 1938. 
